Abstracta Iranica Abstracta Iranica

Revue bibliographique pour le domaine irano-aryen

Volume 25 | 2004

Comptes rendus des publications de 2002

Rāh va rāhsāzī dar İrān. Tehrān, Daftar-e pažūhešhā-ye farhangī, 1381/2002, 100 p. (Az İrān če mìdānam, 24). [Routes et construction de routes en Iran]

\title{
Bernard Hourcade
}

\section{OpenEdition}

Journals

Édition électronique

URL : http://journals.openedition.org/abstractairanica/4986

DOI : 10.4000/abstractairanica.4986

ISSN : 1961-960X

Éditeur :

CNRS (UMR 7528 Mondes iraniens et indiens), Éditions de l'IFRI

Édition imprimée

Date de publication : 15 mai 2004

ISSN : 0240-8910

Référence électronique

Bernard Hourcade, «Rāh va rāhsāzī dar îrān. Tehrān, Daftar-e pažūheš-hā-ye farhangī, 1381/2002,

100 p. (Az Irāan če mìdānam, 24). [Routes et construction de routes en Iran] », Abstracta Iranica [En ligne], Volume 25 | 2004, document 269, mis en ligne le 15 mars 2006, consulté le 25 septembre 2020. URL: http://journals.openedition.org/abstractairanica/4986; DOI : https://doi.org/10.4000/ abstractairanica. 4986

Ce document a été généré automatiquement le 25 septembre 2020.

Tous droits réservés 


\section{Rāh va rāhsāzì dar İrān. Tehrān, Daftar-e pažūheš-hā-ye farhangī, 1381/2002, 100 p. (Az İrān če mìdānam, 24). [Routes et construction de routes en Iran]}

\section{Bernard Hourcade}

\section{INDEX}

Thèmes : 10. Histoire des Sciences et des Techniques nompropre Qâjârs

\section{AUTEURS}

BERNARD HOURCADE

CNRS - Paris 